\title{
Effects of Economic Inequality on Academic Achievement: The Black Boy Dilemma
}

\author{
Tanisha Shirelle Pruitt ${ }^{1 *}$, Sharon Olanike Nicholas-Omoregbe ${ }^{2}$, Jacqueline Bergdahl ${ }^{3}$, \\ Nicholas Nomoregbe ${ }^{2}$, Victor Mbarika ${ }^{4}$ \\ ${ }^{1}$ Southern University and Agricultural and Mechanical College Nelson Mandela School of Public Policy, Baton Rouge, Louisiana, \\ USA \\ ${ }^{2}$ Covenant University, Ota, Ogun, NIGERIA \\ ${ }^{3}$ Wright State University College of Liberal Arts, Dayton, Ohio, USA \\ ${ }^{4}$ ICT University, Baton Rouge, Louisiana, USA
}

Received 2 April 2018 - Revised 16 October 2018 • Accepted 21 December 2018

\begin{abstract}
This study examined the effects of economic inequality on the academic achievement of the African-American males. African-American males are disproportionately poor, many living below the poverty line. The neighborhoods African-American males live in have few resources for learning which fosters low academic achievement. Predictions were made that African- American males in poor families will have lower academic achievement than white males and that African-American males who live in impoverished neighborhood environments attend blighted schools which affect their academic achievement. Regression analyses yielded results showing poverty as statistically significant; however poverty alone was not the only predictor on the outcome of academic achievement. The research findings of this study evoke the need for further research into the decline of academic achievement among African-American males. Policy recommendations for the alleviation of the problem circumscribe the problem of school finance at the local, state, and federal level.
\end{abstract}

Keywords: African-American males, poverty, academic achievement

\section{INTRODUCTION}

The issue of inequality, which obviously seems to be having a ripple effect on virtually every part of the American society and especially in the educational sector, is becoming an issue of concern.

In America today, 54\% of African-Americans graduate from high school, compared to more than $75 \%$ for their Caucasian and Asian counterparts. African-American male students were nearly 2.5 times more likely to be suspended in 2000 than their peers. African-American males' twelfth-grade reading scores are currently lower than any other racial or ethnic group. According to the congressional black caucus foundation, black males ages 18 and older make up $5.5 \%$ of college students, and of those who do make it to college, only one out of every six of them receive a college degree (citation removed as revision from reviewer 2).

In 2015, the National Association for the Advancement of Colored People (NAACP), found that although African-Americans and Hispanics make up 32\% of the population, they are comprised of $56 \%$ of all incarcerated people. There are more African-American males in prison than there are enrolled in schools grades k-12. AfricanAmerican males' academic success has reached a state of emergency in this country. The focus of this research is on the academic success for African-American males because ever since the feminization of education, the educational attainment and success for males is steadily declining. The feminization of education involves a new movement in education that we have been seeing grow over the past decade where women are having higher levels

(C) 2019 by the authors; licensee Modestum Ltd., UK. This article is an open access article distributed under the terms and conditions of the Creative Commons Attribution License (http://creativecommons.org/licenses/by/4.0/). \tanisha_pruitt_00@subr.edu pruittts@muohio.edu (*Correspondence) 


\section{Contribution of this paper to the literature}

- Examining the effects of economic inequality on academic achievement of African-American males is not a new area of interest in research, academia, and legislation. Boschma and Brownstein (2016) found that in almost all major American cities, most African-American and Hispanic students attend public schools where a majority of their classmates qualify as poor or low-income. Additionally, according to a USDA report, poverty among African-Americans exceeds that of any group (Bowman, Comer, Johns, 2018). This article adds further insight into the continuing effects that poverty has on the quality of education a student receives, focusing specifically on the quality of education that African-American males receive in high schools in the nation.

of educational success and attainment. Women are getting higher test scores, higher reading levels, and they are now making up the majority of the population in institutions of higher education. Janet Mulvey, an assistant professor of education at Pace University in New York City, stated that America's boys are being left behind by current practices in the classroom. Boys are dropping out of high schools in significant numbers, failing to complete college degrees, and are behaving more violently (Mulvey, 2009).

Research on the effectiveness of poverty level motivation on the academic achievement of African-Americans is imperative because, the current future of our education system is dismal. Upon his arrival into the oval office, President Trump elected billionaire Betty DeVos as Secretary of Education. Since taking the position DeVos has proposed to cutting $13.6 \%$ or $\$ 9.2$ billion from Department of Education funding. This is critical, as Department of Education currently funds the supports that essential for programs to train, support, and pay teachers. The funding also assists with after school programs for low-income children and families (Whitaker, McDaniels \& Johnson, 2017).

It is important to first examine the underlying factors surrounding the institutional and social issues preventing educational equity for African-American males. For the purposes of this study, we will analyze the effect of economic inequality on academic achievement and outcome.

\section{LITERATURE REVIEW}

In this section, a review was carried out to examine the effects of economic inequality on academic achievement in relation to the African-American males' experience. Some previous related researches were also highlighted.

\section{Public School Structure}

In the poorer neighborhoods where a disproportionate amount of Black teens live, Black students tend to have a lower percentage of graduation rates than white students (Lynch, 2017). Schools attended by Blacks and Hispanics experience a high turnover of teaching and instructional staff. They also have a high number of uncertified or provisionally licensed teachers, and limited access to technology (Nicholas-Omoregbe, Chiazor, Azeta, \& Omoregbe, 2017).

They have few educational specialists and resources, such as, advanced placement classes, limited extracurricular opportunities, and dilapidated physical environments (Rothstein, 2013). Rothstein also notes that schools attended by majorly white students have high-performance, and their staff holds higher degrees and certifications as opposed to schools attended by majorly black students.

Ashenfelter, Collins, and Yoon (2005) found that as of 1960 southern Black teachers had an average of 15.8 years of education (median 16 years) compared to white's average of 15.7 (median 16 years). The disparities among teachers between the educational attainment, cultural competence, and readiness within the different school districts foster an environment of education inequity for students. In the 60's in the South, primarily AfricanAmerican teachers taught African-American students; only white teachers taught few. This caused the students to lag their white peers, because they were taught by less trained teachers. This trend continues in many urban public schools today, where ill equipped teachers with inadequate resources are teaching students. Schools in suburban or rural areas on average have more skilled teachers for their students. Beyond that, they have high technological resources, laboratories to conduct both social and science research, they have advanced placement programs for students to earn college credit, and they have newer facilities (Rothstein, 2013).

Hudley (2013) found that mathematics classes in high-poverty high schools are twice as likely to be taught by a teacher with a credential other than mathematics. In high poverty schools, they suffer from deficient supplies, materials and opportunities to learn, deteriorating physical facilities, which diminish student engagement and performance (Hudley, 2013). 


\section{Public School Resources}

Schools and districts that have the highest percentages of disadvantaged students also tend to have the least access to the resources needed for all students to succeed. Thus, White males in schools and districts with large percentages of Black male students are also likely to experience poor outcomes because of systemic decisions not to commit resources to those districts and schools (Holzman, 2010). Public schools on average are located in urban environments where minorities are the majority. Within these schools, there are inadequate resources that are essential to school success for these students. These schools are old, overcrowded and ill kept. Rothstein also notes that schools attended by majorly white students have high-performance, and their staff holds higher degrees and certifications as opposed to schools attended by majorly black students.

According to Holzman (2010), these students receive watered down curriculum, due to inadequate funding, which causes them to have lower academic achievement in comparison to their peers in successful suburban schools. Lack of computers or updated systems, outdated and tattered textbooks, lack of music and arts programs, and inexperienced and ill-trained teachers, are all evidence of the lack of resources in some public schools. Another factor that contributes to the decline of African-American male achievement is the environment of the AfricanAmerican male student. Our environments play a major role in our development and socialization and when there is social disorganization, or a break down in social order resulting in isolation, within an environment, the academic achievement of these students suffer.

\section{African-American Males, Poverty and Neighborhood Environment}

Living in a low-income blighted urban environment has a direct effect on social disorganization, which involves disorganization among residents in urban areas due to the nature of their environment. Residents experience gang violence, gun violence, and substance abuse, which have a direct effect on their involvement with crime. The home environment can also play a role, as most of our socialization occurs within the home. If there is substance abuse, violence, or drug use in the home, a person is more likely to carry out those same types of behaviors. This type of environment has a detrimental effect on the educational attainment of those who reside within it. Within lowincome neighborhoods, educational attitudes are more unenthusiastic as opposed to middle and upper income neighborhoods. Residents within these neighborhoods have lower levels of educational attainment, so there is a lack of educationally motivated students residing in these communities. Social scientists have compared academic achievement between black and white students in urban and suburban school. According to Pellerin (2005), one difference may be found in the composition of the student bodies in American school districts.

Massey (1996) argues that with the growth of gated communities for the affluent and the further ghettoization of the poor, the United States is becoming more and more fragmented. Clotfeller (2004) argues that neighborhood racial segregation is principally responsible for racial segregation in schools. Students attend schools in the neighborhoods in which they live for the most part, so if the student lives in a racially homogenous environment, they are likely to attend schools of the same nature. The whole notion of Hyper-segregation due to residential discrimination plays a major role in school segregation. African-Americans neighborhoods are isolated within cities, poverty stricken and possess limited resources.

There is a lack of adequate shelter, limited funding for city repairs or aid, unemployment is high so there are a lot of poor people living in these areas, and there is limited amount of food resources. Consequently, the schools that are within these neighborhoods share the same conditions that results in inadequate schools and low academic performance.

An even wider concern is that across various dimensions of difference, such as racial and ethnic background, class, and life cycle, Americans are withdrawing, willingly or not, into homogeneous and defensive enclaves. Racial segregation and housing discrimination are causing the isolation of African-Americans into poorer neighborhoods. Lavine (2008) wrote that segregation is important because the concentration of disadvantage can accentuate problems, such as, academic failure. Iceland, Weinberg, \& Steinmetz (2002) describe racial segregation as the distribution of different groups across units within a larger area. They operationalize their concept of racial segregation by incorporating Massey and Denton's measures of racial segregation: evenness, exposure, concentration, centralization, and clustering. Evenness refers to the differential distribution of the subject population, how evenly spaced are these groups within their given population; exposure measures the potential contact between groups; concentration is the relative amount of physical space occupied; centralization involves the degree to which groups are located near the center of an urban area; and clustering measures the degree to which minority group members live disproportionately in contiguous areas (Iceland, Weinberg, \& Steinmetz, 2002).

Guo Wilson, and Corbet (2001), found a direct relationship between poverty and school disengagement. Students who live in impoverished areas are less likely to be fully engaged in school as some of their more economically stable peers because their parents may not have had the best educational experience because of their 
Table 1. Percentage of students living in poverty 2012-2016

\begin{tabular}{|c|c|c|c|c|c|c|c|}
\hline Location & Race & Data Type & 2012 & 2013 & 2014 & 2015 & 2016 \\
\hline \multirow{14}{*}{ United States } & \multirow{2}{*}{ American Indian } & Number & 259,000 & 254,000 & 250,000 & 233,000 & 242,000 \\
\hline & & Percent & $37 \%$ & $37 \%$ & $36 \%$ & $34 \%$ & $34 \%$ \\
\hline & \multirow{2}{*}{ Asian and Pacific Islander } & Number & 501,000 & 473,000 & 459,000 & 455,000 & 441,000 \\
\hline & & Percent & $15 \%$ & $14 \%$ & $13 \%$ & $13 \%$ & $12 \%$ \\
\hline & \multirow{2}{*}{ Black or African-American } & Number & $4,093,000$ & $4,008,000$ & $3,933,000$ & $3,719,000$ & $3,468,000$ \\
\hline & & Percent & $40 \%$ & $39 \%$ & $38 \%$ & $36 \%$ & $34 \%$ \\
\hline & \multirow{2}{*}{ Hispanic or Latino } & Number & $5,832,000$ & $5,717,000$ & $5,659,000$ & $5,446,000$ & $5,124,000$ \\
\hline & & Percent & $34 \%$ & $33 \%$ & $32 \%$ & $31 \%$ & $28 \%$ \\
\hline & \multirow{2}{*}{ Non-Hispanic White } & Number & $5,206,000$ & $5,108,000$ & $4,854,000$ & $4,645,000$ & $4,326,000$ \\
\hline & & Percent & $14 \%$ & $14 \%$ & $13 \%$ & $12 \%$ & $12 \%$ \\
\hline & \multirow{2}{*}{ Two or more races } & Number & 979,000 & 977,000 & 978,000 & 941,000 & 944,000 \\
\hline & & Percent & $24 \%$ & $23 \%$ & $22 \%$ & $21 \%$ & $20 \%$ \\
\hline & \multirow{2}{*}{ Total } & Number & $16,397,000$ & $16,087,000$ & $15,686,000$ & $15,000,000$ & $14,116,000$ \\
\hline & & Percent & $23 \%$ & $22 \%$ & $22 \%$ & $21 \%$ & $19 \%$ \\
\hline
\end{tabular}

Source: Population Reference Bureau, analysis of data from the U.S. Census Bureau, Census 200 Supplemental Survey, 2001 Supplemental Survey, 2002 through 2016 American Community Survey.

circumstances, so the values on education would not be as strong in their household, causing a cycle of school disengagement.

The United Nations Educational, Scientific, and Cultural Organization (UNESCO) define poverty in two terms, absolute or relative. Absolute poverty measures poverty in relation to the amount of money necessary to meet basic needs such as, food, clothing, and shelter. It is when a family's income fails to meet a federally established threshold that can differ across countries. Whereas relative poverty involves the relationship to the economic status of other members of the society, meaning, where you are in comparison with everyone else in society, it is the class system (UNESCO, 2010).

According to the 2012 U.S. Census Bureau American Community Survey, the poverty rate for all AfricanAmericans in 2012 was $28.1 \%$, which is an increase from $25.5 \%$ in 2005. Black families with children under 18 headed by a single mother have the highest rate of poverty at $47.5 \%$ compared to only $8.4 \%$ of married-couple Black families. According to the U.S. Census Bureau, 11.5\% of African-Americans live in government housing or section 8 housing while $13.6 \%$ receive TANF cash assistance, formerly referred to as welfare checks. Table 1 illustrates the percentage of students living in poverty from 2012-2016 in the United States.

The data in Table 1 shows that African-American students have the highest rates of poverty in the United States as indicated in the total column at the bottom of the table. The total column illustrates the total number of students living in poverty across all races/ ethnicities for each of the specified years. Noguera (2003) stated that the effects of growing up in poverty, particularly for children raised in socially isolated, economically depressed urban areas, warrants greater concern, especially given that 1 out of every 3 Black children is raised in a poor household. Noguera (2003) also says that some schools are sites where Black males are marginalized and stigmatized and Black males are more likely to be labeled with behavioral problems and as less intelligent even while they are still very young.

Hannon (2013) states that poverty causes higher rates of delinquency, and this affect educational achievement negatively. Inner city youth experience natural disadvantages in performing well in school because of their environments. Merton (1973) coined the concept cumulative disadvantage, which refers to the negative experiences in adolescence that put you at a disadvantage in terms of advancement and employment opportunities. The poor youth have less room for mistakes. They have to work twice as hard in order to try and accomplish educational excellence and employment because of the disadvantages that were already set in place early on.

Pellerin (2005) found that African-Americans and other Students of Color have higher numbers in schools with a higher concentration of minorities. There is no support for public schools from upper and middle-income families because they would rather place their teens in private schools where the population is majority White. In urban public schools, many students and their families are at an economic disadvantage according to Hudley (2013). She found that $64 \%$ of students receive free or reduced-price lunches, indicating that their families are at or near the federal poverty level.

Ashenfelter, Collins, and Yoon (2005) discovered through their research that while school resource disparities attribute to lower educational attainment for African-American students, it is the family's economic resources that cause the greatest disadvantages. Their data showed that a family's annual income determine the academic success of the student. African-American families tend to have lower annual income than their white counterparts, which puts them at greater disadvantages academically. Lower educational attainment equals lower potential earning 
income throughout a person's lifetime, which attributes to the current economic state of many African-American families and their children. African-Americans attend schools that tend to be more populated than other schools and have a higher teacher to student ratio than White students.

\section{THEORETICAL FRAMEWORK}

This research is based on one theoretical framework, social disorganization theory. The social disorganization theory comes from the Chicago school of sociology in the early 1920s and can be defined as the decline of influence of existing social rules of behavior upon individuals within a group (Wong, 2000). Social disorganization theory got its start beginning in 1909 when Warming; a plant biologist proposed that plants live in "communities" with varying states of symbiosis, or natural interdependence. He found that communities containing plants predominantly of the same species were more in competition with nature than with each other, whereas, communities with several different species competed for limited resources more among themselves than with the environment (Miller, 2009).

Sociologists Clifford Shaw and Henry D. McKay developed the theory into what we know today in 1942. Social disorganization is the consequence of a community's inability to realize common values and to solve the problems of its residents, resulting in the breakdown of effective social control within that community. Social disorganization theory states that low educational success was not caused at the individual level but was considered to be the normal response of normal individuals to abnormal social conditions. Shaw and McKay developed their theory off of the following urban ecological characteristics; 1) Physical status, 2) Economic status, and 3) Population status. In terms of physical status, they found that high disorganization occurs within areas that are physically deteriorated, near areas of heavy industry, and populated with transient residents.

In regards to economic status, he found that, affluent areas have more social control and less disorganization, whereas, low affluent areas have more disorganization because of the diversity of its residents. Finally, population status has an impact on social disorganization because, delinquency in low-income areas become competitive due to the high concentrations of people in these environments. Resources become scarce and limited, so everyone is in competition for them, causing disorganization (Miller 2009). Social disorganization also has adverse effects on educational outcomes for the residents in these disorganized communities. Many residents in these low affluent communities, have lower educational attainment, earn lower wages, and are more involved in deviant and criminal behavior.

Roach (2004) found that according to the National Assessment of Educational Progress, the average Black 12th grade student's proficiency is roughly the same as the average White eighth grader. Social disorganization theory can be effective when trying to understand the social issues surrounding the achievement gap between black and white students. Madyun (2011) describes how the different factors of social disorganization attribute to understanding the achievement gap in education research. He broke social disorganization theory into the following factors:

Factor 1: Family Composition (single parent households). He found that having fewer two-parent families in a community typically result in less adult supervision and fewer role models to attribute to positive educational attitudes.

Factor 2: Residential Mobility. Population turnover reduces the probability of long-standing relationships, which results in weaker social ties (relationship to a potential resource). Social ties can be strong (close, frequent relationship) or weak (distant, infrequent relationship). Population turnover also results in less social capital (the actual and potential resources embedded in social ties that can be used to achieve an outcome), poorer quality resources, and lack of access to resources and opportunities.

Factor 3: Racial Diversity. Cultural barriers are particularly important when considering achieve gap factors focused on parental/family attributes and school quality.

Factor 4: Poverty. Poorer communities include many residents who lack the money and resources necessary to pass on and enforce normative expectations and behavior. Maydun (2011) states that because of limited money and resources, it would be difficult for community members to participate in the organizations necessary to establish positive social ties and generate resources necessary to address academic concerns.

Minorities are consistently in higher rates of poverty placing institutional limits on them through their life span. Their higher rates of poverty greatly affect their academic achievement in schools.

As mentioned above, this research focuses on the educational attainment for African-American males because ever since the movement of the feminization of education, the educational attainment and success for males is steadily declining. 


\section{RESEARCH HYPOTHESIS}

The following hypothesis was used for this study:

$\mathrm{H}_{1}$ : African-American males in both high and low poverty areas will have lower academic achievement than White males due to the effects of social disorganization.

\section{DATA AND METHODS}

In this study, bivariate analysis was used in order to check for the level of relationship that exists between the variables under consideration. Likewise, chi-square test of independence was employed in order to check for the independence of level of poverty and academic achievement, that is, whether academic achievement and poverty are independent.

Also, secondary analysis was used as a method to examine the independent variables on the dependent variable. Institutional Review Board form and protocol was completed (See Appendix A). Secondary analysis on the dataset, 2009 High School Longitudinal Study, was used to run statistical analyses of the IV'S on the DV. The 2009 High School Longitudinal Study was a National longitudinal study of 23,000+ ninth graders from 944 U.S. schools in 2009. The students were followed throughout secondary and postsecondary years. The study includes student surveys, parent surveys, math and science teacher surveys, school administrator surveys, and school counselor surveys. The study focused on student trajectories from the beginning of high school into postsecondary education, the workforce and beyond.

The study is comprised of a few data collection waves. The first wave (base year) was in 2009, the first follow up to the study was conducted in 2012, in 2013 there was an update, and a second follow up was in 2016. The project facilitators noted complications with the survey because of low response rates from both parents and teachers. This made necessary special student weights to be used in the statistical analysis to adjust the data skewed by missing cases. The 2009 High School Longitudinal study of 2009 (HSLS: 2009/13, including HS transcripts) can be found under the EDAT site within the National Center for Education Statistics (NCES) website. For the purposes of this study only the student level files were used.

\section{Independent Variables}

The independent variables for this study are designed to indicate causation of lowered academic achievement among African-American males. Poverty rates which is an ordinal level variable, is defined as the set of money income thresholds that vary by family size and composition. If a family is total, income is less than the family's threshold, then the family and every individual in it is considered in poverty (Census.gov). For the purpose of this study, poverty will be measured according to the students' family's annual income, and their location relative to the poverty line. Poverty rates were coded as such; X1FAMINCOME: Total family income from all sources 2008, $0=\$ 35,000-\$ 55,000,1=\$ 55,000-\$ 75,000,2=\$ 75,000-\$ 95,000,3=\$ 95,000-\$ 115,000$, and $4=\$ 115,000-\$ 135,000$.

\section{Dependent Variables}

The dependent variable, academic achievement, which is an ordinal level variable, conceptually means the outcome of education, i.e. the extent to which a student teacher, or institution has achieved their goals. For the purposes of this study, academic achievement was measured according to whether or not the student qualified for financial aid based on academic achievement. Student's qualification based on financial aid was coded as such; S2QUALACHIEVE: will qualify for financial aid based on academic achievement, $1=$ yes, 2=No, and $3=$ do not know. The dependent variable was changed around from the initial variable due to lack of problem with the data. There were too many cases of missing data to allow accurate statistical testing.

\section{Control Variables}

Two control variables had to be coded into SPSS for the statistical analysis portion of this study. These variables are Race, which was coded as X1RACE 1=Black/African-American/Non-Hispanic and two= White, Non-Hispanic. Gender was coded as X1SEX: $1=$ Male $0=$ Female.

\section{Analysis/Results}

For the purposes of this study, a number of tests were used to measure the effects of poverty on academic achievement of African-American males.

Table 2 provides a description of the sample that was used for the purposes of this study. 
Table 2. Description of the Sample

\begin{tabular}{lll}
\hline Variables & Percent \\
\hline Sex & \\
& Male & $51 \%$ \\
& Female & $49 \%$ \\
\hline Race & \\
& Black/ African-American/ & \\
& Non-Hispanic & $83.1 \%$ \\
& \\
$\quad$ White, Non-Hispanic & $16.9 \%$ \\
\hline Location & \\
& City & $28.46 \%$ \\
& Suburb & $36.03 \%$ \\
& Town & $11.86 \%$ \\
& Rural & $23.65 \%$ \\
\hline Median Family Income & \\
$<15,000$ & $11.1 \%$ \\
$\quad>15,000,<\$ 35,000$ & $21.4 \%$ \\
$>\$ 35,000<\$ 55,000$ & $19.5 \%$ \\
$>\$ 55,000,<\$ 75,000$ & $17.7 \%$ \\
$>\$ 75,000,<\$ 95,000$ & $13.1 \%$ \\
$>\$ 95,000,<\$ 115,000$ & $10.5 \%$ \\
$>\$ 115,000,<\$ 135,000$ & $6.8 \%$ \\
\hline
\end{tabular}

Table 3. Bivariate Analysis Students Qualifying for financial aid based on academic achievement Gender, Race, Poverty

\begin{tabular}{|c|c|c|}
\hline Variables & Percent & P-Values \\
\hline \multicolumn{3}{|l|}{ Sex } \\
\hline Male & $51 \%$ & \multirow{2}{*}{.000} \\
\hline Female & $49 \%$ & \\
\hline \multicolumn{3}{|l|}{ Race } \\
\hline Black/African-American/Non- Hispanic & $16.9 \%$ & \multirow{2}{*}{.000} \\
\hline White, Non-Hispanic & $83.1 \%$ & \\
\hline \multicolumn{3}{|l|}{ Location } \\
\hline City & $28.46 \%$ & \multirow{4}{*}{.001} \\
\hline Suburb & $36.03 \%$ & \\
\hline Town & $11.86 \%$ & \\
\hline Rural & $23.65 \%$ & \\
\hline \multicolumn{3}{|l|}{ Median Family Income } \\
\hline$<\$ 15,000$ & $11.1 \%$ & \multirow{7}{*}{.000} \\
\hline$\$ 15,000,<\$ 35,000$ & $21.4 \%$ & \\
\hline$>\$ 35,000,<\$ 55,000$ & $19.5 \%$ & \\
\hline$>\$ 55,000,<\$ 75,000$ & $17.7 \%$ & \\
\hline$>\$ 75,000,<\$ 95,000$ & $13.1 \%$ & \\
\hline$>\$ 95,000,<\$ 115,000$ & $10.5 \%$ & \\
\hline$>\$ 115,000,<\$ 135,000$ & $6.8 \%$ & \\
\hline
\end{tabular}

Among the sample of 23,000 people who were surveyed from 944 schools for the High School longitudinal study 2009-2013 there were majority male respondents (51\%) of whom were also majority White, Non-Hispanic students (83.1\%). Most of the schools that were surveyed were located in the suburbs $(36.03 \%)$ and in the cities $(28.46 \%)$. The median family income among the respondents fell between $\$ 35,000$ and $\$ 55,000$, which can be classified among low to middle socioeconomic status.

Table 3 illustrates results from a binary analysis that was ran on students qualifying for financial aid and academic achievement. The purpose of Table 3 is to show the relationship between financial aid eligibility based on income and academic achievement by gender, race, and socioeconomic status.

The p-values reflected in Table 4 all show values of statistical significance, lending to the effect socioeconomic status has on academic achievement. The variables and measures for the study are found in Table 4. 
Table 4. Variable Table

\begin{tabular}{cc}
\hline Variable Type & Measured \\
\hline Independent Variables & \\
\hline Poverty & $\begin{array}{c}\text { Median Family Income less than } \$ 15,000 \\
\text { Median Family Income greater than } \$ 15,001\end{array}$ \\
\hline
\end{tabular}

Table 5. Academic Achievement and Family Income Cross tabulation

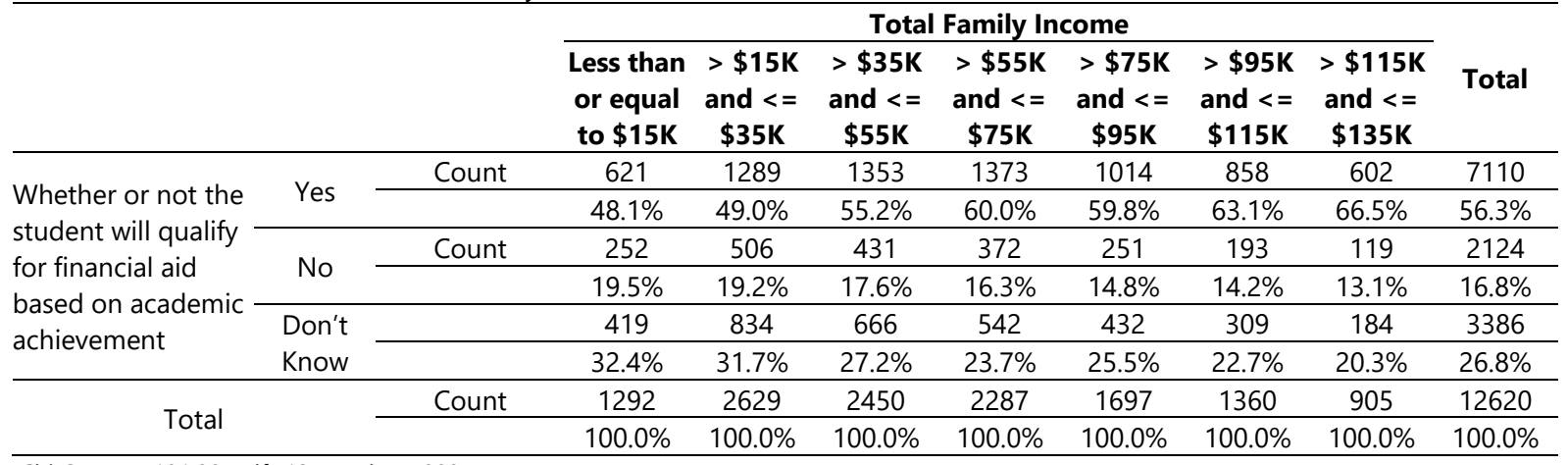

(Chi-Square $=181.895, \mathrm{df}=12, \mathrm{p}$-value $=.000)$

Table 6. Correlation Matrix for key variable for poverty on academic achievement

\begin{tabular}{llllllllll}
\hline Variable & $\mathbf{1}$ & $\mathbf{2}$ & $\mathbf{3}$ & $\mathbf{4}$ & $\mathbf{5}$ & $\mathbf{6}$ & $\mathbf{7}$ & $\mathbf{8}$ \\
\hline
\end{tabular}

\begin{tabular}{|c|c|c|c|c|c|c|c|}
\hline 1. Race & -.016 & $-.086^{\star *}$ & -.003 & -.010 & - & & \\
\hline 2. Sex & $-.028^{* *}$ & $-.070^{* *}$ & $-.038^{\star *}$ & $-.060^{\star *}$ & .011 & - & \\
\hline 3. Below Poverty Line & $-.079^{* *}$ & $-.128^{\star \star}$ & $-.079 * \star$ & $-.073^{\star \star}$ & $.199^{\star \star}$ & .005 & - \\
\hline 4. Academic Achievement & $.154^{\star \star}$ & $.269^{\star \star}$ & $.110^{* \star}$ & $.156^{\star \star}$ & .002 & $-.114^{\star *}$ & $-0.87^{* \star}$ \\
\hline
\end{tabular}

In this study, cross tabulations were run between the individual independent variable poverty and the dependent academic achievement. The variable and measure can be found in Table 5 .

Table 5 shows the relationship between poverty and academic achievement. Almost half (48\%) of the students that have a total family income of less than $\$ 15,000$ believe that they will qualify for financial aid based on their academic achievement. On the other end of the spectrum, more than half (66.5\%) of students that have a total family income between $\$ 115,000$ and $\$ 135,000$, believe that they will qualify for financial aid based on their academic achievement.

The variable chosen does not speak directly to academic achievement, but it shows that through a student's academic achievement they were eligible for financial aid for college after graduation, showing that they must have achieved some level of academic excellence during high school. We can see through these percentages that as income increases, qualifying for financial aid based on academic achievement also increase. The results yielded a $p$ value of .000 , which is statistically significant, showing that there is a correlation between the two variables.

\section{Multivariate Analysis}

For the purposes of this study multiple regression was run to determine the variance between the variable and its effect on academic achievement. To run the variables in regression, our original variables had to be recoded in order to dichotomize them to produce a model with the best fit. X1POVERTY was transformed into Binary Poverty making $0=$ Below the poverty threshold and $1=$ At or above the poverty threshold.

As shown in Table 6, the sex of the student and the student's poverty level were negatively correlated with academic achievement and, both of the variables are significant. Sex having a negative correlation shows us that academic achievement is more geared towards females, which supports our previous predictions. Surprisingly, for race, no significant relationship was found between the race of a student and their academic achievement, yielding a correlation coefficient of .002 , indicating that race alone is not a factor but when coupled with poverty, there are detrimental effects on academic achievement. 
Table 7. Summary of Multiple Regression Analyses for predicting poverty on academic achievement

\begin{tabular}{lccccc}
\hline & Model 1 & Model 2 & Model 3 & Model 4 & Model 5 \\
\hline Variable & B SE B $\boldsymbol{\beta}$ & B SE B $\boldsymbol{\beta}$ & B SE B $\boldsymbol{\beta}$ & B SE B $\boldsymbol{\beta}$ & B SE B $\boldsymbol{\beta}$ \\
\hline Binary_Sex & & & & $-.072 .01-.07^{* *}$ & $-.07 .01-.07^{* *}$ \\
\hline Binary_X1Poverty & & & & $.29 .07 .05^{\star *}$ \\
\hline Rsquared & .05 & .07 & .08 & .09 & .09 \\
\hline Depres
\end{tabular}

Dependent Variable: Academic Achievement

${ }^{*} p<.05 .{ }^{* *} p<.01 .{ }^{* * *} p<.001$

Table 7 shows us the summary of multiple regression analyses for predicting poverty on academic achievement.

For the purposes of this study, a multilinear regression was run in order to predict academic achievement based on their poverty level, and their race. The overall regression model only recognized two predictors (Student' sex and poverty level), that significantly predict student's poverty on their academic achievement This model accounted for $9.3 \%$ of variance in academic achievement.

\section{FINDINGS/DISCUSSION}

The data results in this study proved the hypothesis true. The alternative hypothesis, H1: African-American males in poor families will have lower academic achievement than White males was proven true through correlations and multiple regression of poverty on academic achievement. The results yielded a $p$ value of .000 , which is statistically significant, showing that there is a correlation between poverty and academic achievement. This is in line with the findings of Guo, Wilson, and Corbet (2001) who found a direct relationship between poverty and school disengagement. Additionally, the outcomes of this study support other scholars noted in the literature who have similarly found a correlation between economic inequality and poverty. For instance, Rothstein (2013) found that in low-income neighborhoods, the residents are of low socioeconomic status, and black students in these neighborhoods have lower graduation rates compared to their white peers. He said that schools in these lowincome communities have few educational specialists and resources, such as advanced placement classes, limited extracurricular opportunities, and dilapidated physical environments. Additionally, Holzman (2010) found that within low-income schools, there are inadequate resources that are essential for the academic success of AfricanAmerican students within those schools. These students receive watered down curriculum, due to inadequate funding, which causes them to have lowered academic achievement in comparison to their peers in successful suburban schools.

Similarly, Reardon (2011) and Walsh and Theodorakakis (2017) both discovered that income inequality has caused a growth in educational inequality. Growing poverty rates have led to the widening of the achievement between students of color and their peers. Family income has an impact on the educational opportunities that are available to children. Children and teens in low-income families often have less access to educational opportunities, such as, educational programs both within and outside of school, which affect their academic achievement. However, Rothstein (2013) found that while low-income has an effect on educational outcomes, it is not a direct cause of low academic achievement. They went on to say that even after controlling for poverty, black achievement is still lower than white achievement because there are other factors that must be considered. In other words, poverty rate alone is not an adequate explanatory factor of low academic achievement.

Following the theoretical framework of our study, that is, social disorganization, it was found that economic inequality leads to social disorganization, which also has adverse effects on educational outcomes for the residents in disorganized communities. Many residents in low affluent communities, have lower educational attainment, earn lower wages, and are more involved in deviant and criminal behaviors. Students who live in impoverished areas are less likely to be fully engaged in school as some of their more economically stable peers because their parents may not have had the best educational experience due to their circumstances, so the values on education would not be as strong in their household, causing a cycle of school disengagement.

\section{CONCLUSION/POLICY IMPLICATIONS}

This study looked at the effects of poverty on the academic achievement of African-American males. The data results showed that poverty has a significant effect on academic achievement. Although, students being in better schools or school districts, does not always equate to students receiving a quality education.

The study focuses on a macro level analysis of the data across time, which can allow for more broad data and implications. In view of the findings from this research, it is suggested that later or future research should focus on 
more contemporary issues, such as, unequal educational technology access, school funding disparities and economic issues plaguing the African-American community that continue to persist.

It is hoped that the research and data from this study can assist policy makers for educational reform with future policies and funding for improving the educational attainment for African-American males. Specifically, policy makers should consider the data in order to allocate funding, provide more extensive teacher training, and greater resources in order to bring the black boys back up to speed in educational attainment and success.

\section{REFERENCES}

Ashenfelter, O., Collins, W. J., \& Yoon, A. (2006). Evaluating the role of brown vs. board of education in school equalization, desegregation, and the income of African-Americans. American Law and Economics Review, 8(2). https:/ / doi.org/10.1.1.559.9860\&rep=rep1\&type

Boschma, J., \& Brownstein, R. (2016). The Concentration of Poverty in American Schools. Next American: CommunitiesThe Atlantic. Retrieved from https://www.theatlantic.com/education/archive/2016/02/ concentration-poverty-american-schools/471414/

Bowman, B., Comer, J., \& Johns, D. (2018). Addressing the African-American Achievement Gap: Three Leading Educators Issue a Call to Action. Young Children, 73(2). Retrieved from https://www.naeyc.org/resources/pubs/yc/may2018/achievement-gap

Burch, T. (2014). The old Jim Crow: Racial residential segregation and neighborhood imprisonment. Law E Policy, 36(3), 223-255. https:/ / doi.org/10.1111/lapo.12022

Bursik JR., R. J. (1988). Social disorganization and theories of crime and delinquency: Problems and prospects. Criminology, 26(4), 519.

Colemen, J., Campbell, E., Hobson, C., McPartland, J., Mood, A., Weinfeld, F., \& York, R., (1966). Equality of educational opportunity: The coleman report. In Arum, Richard., Beattie, Irenee., \& Ford, Karly. (Ed.), The structure of schooling: Readings in the sociology of education (pp. 120-136). Thousand Oaks, California: Pine Forge Press.

Denton, N. A. (2007). Hypersegregation. Blackwelll Encyclopedia of Sociology, June 25th, 2015. https:/ / doi.org/10.1111/b.9781405124331.2007.x

Feierman, L. (2014). Troubling statistics for African-American males in the classroom. Retrieved from http:// sanfrancisco.cbslocal.com/2014/04/10/troubling-statistics-for-african-american-males-in-the-classroom/

Goldsmith, P.A. (2003). All Segregation is Not Equal: The Impact of Latino and Black School Composition. Sociological Perspectives, 46(1), 83-105. https:/ / doi.org/10.1525/sop.2003.46.1.83

Holzman, M. (2010). Yes we can: The Schott 50 states report on public education and black males. Schott Foundation for Public Education.

http:/ / datacenter.kidscount.org/ data/tables / 44-children-in-poverty-by-race-and-ethnicity\#detailed/1/any / false/870,573,869,36,868/10,11,9,12,1,185,13/324,323

http://www.naacp.org/criminal-justice-fact-sheet/

https://nces.ed.gov/programs/coe/indicator_clb.asp

Hudley, C. (2013). Education and urban schools. American Psychological Association.

Hunter, R. C. (2011). Public school desegregation and education facilities. School Business Affairs.

Iceland, J., Weinberg, D., \& Steinmetz, E. (2002). 'Racial and Ethnic Residential Segregation in the United States: 1980-2000’, Census 2000 Special Report series no.CENSR-3. Bureau of Census, US Department of Commerce, Washington DC.

Johnson, S. M., Kardos, S. M., Kauffman, D., Liu, E., \& Donaldson, M. (2004). The support gap: New teachers' early experiences in high-income and low-income schools. Education Policy Analysis Archive, 12(61). https://doi.org/10.14507/epaav12n61.2004

Lavine, G. (2008). A Foucaultian Approach to Academic Anxiety. Educational Studies: Journal of the American Educational Studies Association, 44, 62-76. https:/ / doi.org/10.1080/00131940802225101

Lynch, M. (2017). Black Boys in Crisis: The Intersection of Poverty and Education. Retrieved from http:/ / www.theedadvocate.org/black-boys-in-crisis-the-intersection-of-poverty-and-education/

Madyun, N. H. (2011). Connecting social disorganization theory to African American outcomes to explain the achievement gap. Educational Foundations.

Massey, D. S., \& Denton, N.A. (1989). “Hypersegregation in US Metropolitan Areas: Black and Hispanic Segregation along Five Dimensions." Demography, 26, 373-92. 
Massey, D. S., \& Denton, N.A. (2004). “The Dimensions of Residential Segregation.” Social Forces, 67, $281-315$. https:// doi.org/10.1177/0049124196025002002

Miller, M. J. (2009). 21st century criminology: A reference handbook social disorganization theory . Sage Publications, https:/ / doi.org/10.4135/9781412971997

Mulvey, J. D. (2009). Feminization of Schools. School Administrator, 66(8), 34-36.

Nicholas-Omoregbe, O. S., Azeta, A. A., Chiazor, I. A., \& Omoregbe, N. I. (2017). Predicting the Adoption of ELearning Management System: A Case of Selected Private Universities in Nigeria. Turkish Online Journal of Distance Education TODJE, Turkey, 18(2), 106-121.

Noguera, P. A. (2003). The Trouble with Black Boys: The role and influence of environmental and cultural factors on the academic performance of African American males. Sage, 38(4).

Reardon, S. (2011). The Widening academic achievement gap between the rich and the poor: New evidence and possible explanations. Russell Sage Foundation. Retrieved from http://cepa.stanford.edu/ content/widening-academic-achievement-gap-between-rich-and-poor-new-evidence-and-possible

Rice, J. K., \& Roelke, C. (2003). Urban school finance: Increased standards and accountability in uncertain economic times. School Business Affairs, 69, 30-33.

Roach, R. (2004). The great divide. Black Issues in Higher Education, 21(1), 22-25.

Rothstein, R. (2013). For Public Schools, Segregation Then, Segregation Since: Education and the Unfinished March. Economic Policy Institute. Retrieved from http:/ / docshare04.docshare.tips/files/17180/171804363. pdf

U.S. Census (2015). Poverty. Retrieved from: http:/ /www.census.gov/hhes/www/poverty/methods/definitions. html

U.S. Census Bureau. (2013). US Department of Commerce, census bureau, current population survey (CPS). "Annual Social and economic supplement" 1990-2013.

UNESCO. (2010). Poverty. Retrieved on November 18, 2014 from http://www.unesco.org/new/en/social-andhuman-sciences/themes/international-migration/glossary/poverty/

Walsh, M., \& Theodorakakis, M. (2017). The Impact of Economic Inequality on Children's Development and Achievement. Religions, 8(67).

Ware, L. (2002). Race and urban space: Hypersegregated housing patterns and the failure of school desegregation. Widener Law Symposium.

Whitaker, C., McDaniels, A., \& Johnson, S. (2017). The Trump Adminstration's slow but steady undoing of the Department of Education. Retrieved from https://www.americanprogress.org/issues/education-k12/news/2017/11/20/442737/trump-administrations-slow-steady-undoing-department-education/

Williams, T.R., Davis, L.E., Saunders, J. Williams, J. H. (2002). Friends, family, and neighborhood: Understanding academic outcomes of African American youth. Sage Publications, 37(3). https:/ / doi.org/10.177/00485902037003006

\section{http://www.ejmste.com}

